\title{
Gambaran histopatologik hati tikus wistar yang diberi minuman kopi pasca induksi karbon tetraklorida $\left(\mathrm{CCl}_{4}\right)$
}

\author{
${ }^{1}$ Sulistia Pratiwi \\ ${ }^{2}$ Meilany F. Durry \\ ${ }^{2}$ Carla Kairupan
}

\author{
${ }^{1}$ Kandidat Skripsi Fakultas Kedokteran Universitas Sam Ratulangi Manado \\ ${ }^{2}$ Bagian Patologi Anatomi Fakultas Kedokteran Universitas Sam Ratulangi Manado \\ Email: sulistiap12216@yahoo.co.id
}

\begin{abstract}
Liver is the central of body metabolism and therefore is the major organ that suffers the most when subjected to free radicals and toxins, e.g carbon tetrachloride $\left(\mathrm{CCl}_{4}\right)$. One of the herbal plants that is useful for treating liver damage is coffee. Coffee beans contains chlorogenic acid, an antioxidant, that can prevent liver damage. This study aimed to obtain a histopathological features of the liver of Wistar rats administered with coffee after induced with $\mathrm{CCl}_{4}$. This was a laboratory experimental study. Samples were 24 Wistar rats (Rattus norvegicus) divided into four groups. Rats in group 1 were the negative control. Rats in group 2 were induced with $\mathrm{CCl}_{4} 0.05 \mathrm{ml} /$ day for 5 days. Rats in group 3 were induced with $\mathrm{CCl}_{4}$ $0.05 \mathrm{ml} /$ day for 5 days, followed by coffee administration $1 \mathrm{ml} /$ day for 7 days. Rats in group 4 were induced with $\mathrm{CCl}_{4} 0.05 \mathrm{ml} /$ day for 5 days then were given no treatment for 7 days. Termination was done on day 6 (group 1 and 2) and day 13 (group 3 and 4). The results showed that rats in group 2 histophatologically showed fatty liver formation and inflammation. Rats in group 3 were the same as group 4 in the terms showed regeneration of hepatocytes. Conclusion: Administration of coffe $1 \mathrm{ml} /$ day (single dose) for seven days after induction with $\mathrm{CCl}_{4}$ for five days showed regeneration of hepatocytes which was similar to that in physiological condition.
\end{abstract}

Keywords: histopathological features of the liver of wistar rats, carbon tetrachloride, coffee

\begin{abstract}
Abstrak: Hati merupakan pusat metabolisme tubuh sehingga menjadi organ utama yang mengalami kerusakan karena terpapar oleh radikal bebas dan bahan toksik seperti karbon tetraklorida $\left(\mathrm{CCl}_{4}\right)$. Tanaman herbal yang berkhasiat mengobati kerusakan hati yaitu kopi. Biji kopi mengandung asam klorogenat yang bersifat antioksidan kuat yang dapat mencegah kerusakan hati. Penelitian ini bertujuan untuk mendapatkan gambaran histopatologik hati tikus Wistar yang diberikan minuman kopi pasca induksi $\mathrm{CCl}_{4}$. Jenis penelitian ini eksperimental laboratorik yang menggunakan 24 ekor tikus Wistar spesies Rattus norvegicus. Hewan uji dibagi dalam 4 kelompok. Kelompok 1 sebagai kontrol negatif, kelompok 2 diinduksi $\mathrm{CCl}_{4}$ $0,05 \mathrm{ml} /$ hari selama 5 hari, kelompok 3 diinduksi $\mathrm{CCl}_{4} 0,05 \mathrm{ml} /$ hari selama 5 hari kemudian diberikan minuman kopi $1 \mathrm{ml} /$ hari selama 7 hari, kelompok 4 diinduksi $\mathrm{CCl}_{4}$ 0,05 ml/hari kemudian tidak diberi perlakuan selama 7 hari. Kelompok 1 dan 2 diterminasi pada hari ke-6, sedangkan kelompok 3 dan 4 diterminasi pada hari ke-13. Hasil penelitian menunjukkan bahwa kelompok 2 menunjukkan adanya perlemakan sel hati dan peradangan. Kelompok 3 menunjukkan hasil yang mirip dengan kelompok 4 yaitu adanya regenerasi sel-sel hati. Simpulan: Pemberian minuman kopi $1 \mathrm{ml} /$ hari dosis tunggal selama tujuh hari pasca induksi $\mathrm{CCl}_{4}$ selama lima hari menunjukkan gambaran histopatologik berupa regenerasi sel-sel hati yang mirip dengan regenerasi sel-sel hati yang terjadi secara fisiologik.
\end{abstract}

Kata kunci: gambaran histopatologik hati tikus wistar, karbon tetraklorida, minuman kopi. 
Hati merupakan organ tubuh yang berperan dalam metabolisme lemak, karbohidrat, protein serta dalam detoksifikasi sehingga menyebabkan hati menjadi organ utama yang mengalami kerusakan. ${ }^{1}$ Kerusakan pada hati berkaitan dengan adanya gangguan fungsi hati akibat paparan obat atau bahan kimia yang disebut hepatotoksisitas. $^{2}$

Hati mengandung sel-sel yang mempunyai kesanggupan melakukan mekanisme berkompromi dengan reactive oxygen species (ROS). Reactive oxygen species (ROS) merupakan suatu zat peroksidasi yang sangat reaktif dan tergolong dalam kelompok radikal bebas. ${ }^{3}$

Radikal bebas serta zat toksik yang berlebihan berperan penting dalam kerusakan hati. Penelitian terhadap radikal bebas sering menggunakan karbon tetraklorida $\left(\mathrm{CCl}_{4}\right)$ sebagai induksi kerusakan hati. Karbon tetraklorida termasuk senyawa halogen hidrokarbon alifatik yang banyak digunakan sebagai pelarut, peptisida, bahan pendingin, penghilang noda dan sabun. ${ }^{4,5}$ Senyawa ini dapat masuk ke dalam tubuh manusia secara inhalasi, tertelan, kontak dengan mata dan kontak langsung dengan kulit. Dalam tubuh $\mathrm{CCl}_{4}$ dapat menimbulkan kerusakan pada hati, ginjal, paru, otak dan dicurigai sebagai penyebab kanker. ${ }^{6}$

Tanaman herbal yang berkhasiat untuk mengobati kerusakan hati di antaranya ialah kopi. ${ }^{7}$ Biji kopi mengandung senyawa kimia volatile dan non-volatile. Senyawa volatile berpengaruh terhadap aroma kopi sedangkan senyawa non-volatile berpengaruh terhadap mutu kopi. Asam klorogenik yang terkandung dalam biji kopi merupakan salah satu jenis senyawa polifenol yang bersifat antioksidan kuat yang mampu mencegah kerusakan hati. ${ }^{7}$

Mekanisme kerja yang bertanggung jawab terhadap efek kopi di hati terletak pada tiga komponen utama dalam kopi yaitu kafein, diterpenes (kafestol dan kahweol), dan asam klorogenat. Kafein menghambat ekspresi faktor pertumbuhan jaringan ikat di sel-sel hati, sehingga menginduksi degradasi proteasomal faktor pertumbuhan jaringan ikat yaitu transforming growth factor beta (TGF- $\beta$ ) dari mediator sinyal Smad2, menghambat fosforilasi Smad3 dan Smad1, dan upregulation reseptor aktivasi proliferator peroksisom. ${ }^{3}$ Penelitian ini bertujuan untuk mengetahui gambaran histopatologik hati tikus wistar yang diberikan minuman kopi pasca induksi $\mathrm{CCl}_{4}$.

\section{METODE PENELITIAN}

Jenis penelitian ini ialah eksperimental laboratorik yang dilakukan pada bulan September 2015 sampai Februari 2016 di bagian Patologi Anatomi Fakultas Kedokteran Universitas Sam Ratulangi Manado. Subjek penelitian ialah 24 ekor tikus Wistar spesies Rattus novergicus jantan dengan berat rata-rata 200 g. Minuman kopi yang digunakan pada penelitian ini dibuat dari biji kopi yang berasal dari daerah Kotamobagu yang dikeringkan dan dihaluskan. Bubuk kopi tersebut dilarutkan dalam air panas kemudian didinginkan dan diberikan pada tikus menggunakan sonde lambung dengan dosis $1 \mathrm{ml} /$ hari dosis tunggal. Karbon tetraklorida yang digunakan berasal dari golongan halogen alifatik dalam bentuk cair. Dosis $\mathrm{CCl}_{4}$ yang digunakan untuk kerusakan hati yaitu $0,05 \mathrm{ml} /$ hari. $^{8}$

Subjek penelitian dibagi dalam 4 kelompok, yaitu kelompok kontrol negatif, hanya diberi makan pellet biasa selama 5 hari; kelompok 2, diinduksi $\mathrm{CCl}_{4}$ dosis 0,05 $\mathrm{ml} /$ hari selama 5 hari; kelompok 3 , diinduksi $\mathrm{CCl}_{4}$ dosis $0,05 \mathrm{ml} /$ hari selama 5 hari kemudian diberikan minuman kopi 1 $\mathrm{ml} /$ hari selama 7 hari; dan kelompok 4, diinduksi $\mathrm{CCl}_{4}$ dosis $0,05 \mathrm{ml} /$ hari selama 5 hari kemudian tidak diberi perlakuan selama 7 hari. Kelompok 1 dan 2 diterminasi pada hari ke-6, sedangkan kelompok 3 dan 4 diterminasi pada hari ke13. Organ hati diproses untuk pembuatan preparat histopatologik untuk evaluasi gambaran mikroskopik jaringan hati.

\section{HASIL PENELITIAN}

Pada tikus wistar kelompok 1 (kontrol negatif) didapatkan gambaran jaringan hati 
normal. Arsitektur hati baik, terdiri dari selsel hati yang tersusun rapi seperti pita memanjang dengan vena sentralis yang berada di tengah dan segitiga Kiernan (Gambar 1).

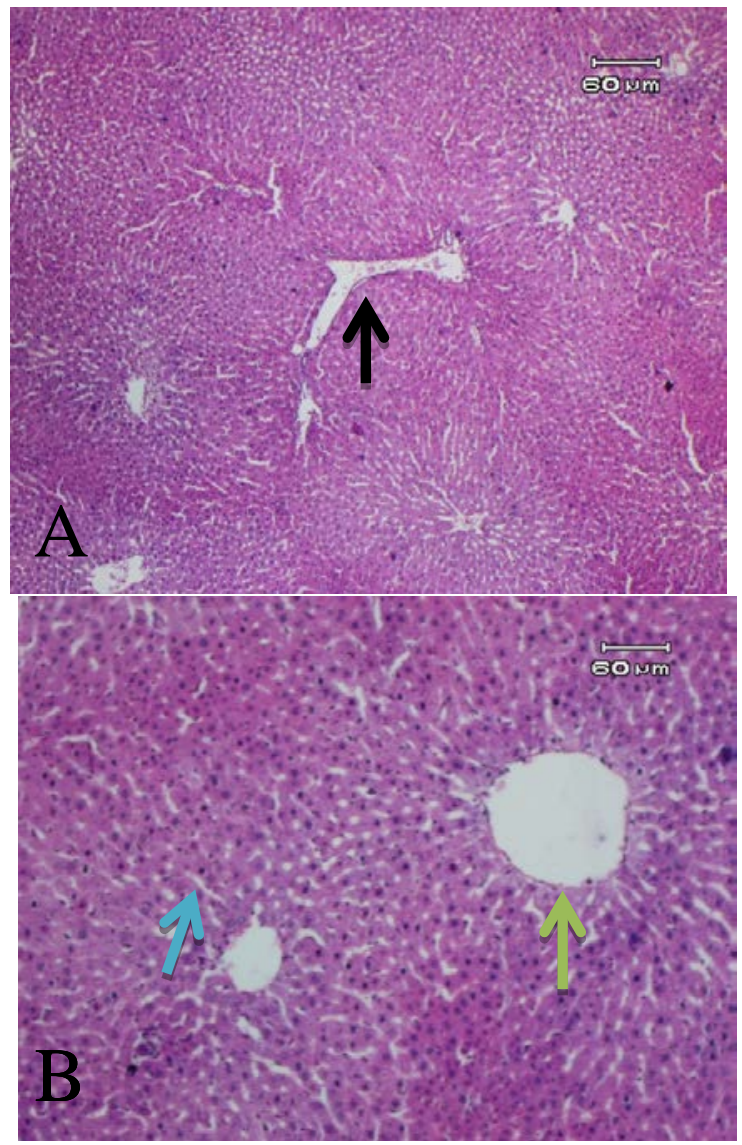

Gambar 1. Gambaran mikroskopik hati tikus wistar kontrol negatif (terminasi hari ke-5). Tampak sel-sel normal hati (panah biru) dengan vena sentralis di tengah (panah hijau), dan segitiga kiernan (panah hitam). A, Pembesaran 40x ; B, pembesaran 100X.

Pada kelompok 2 jaringan hati tikus menunjukkan adanya nekrosis yang luas sehingga struktur sel tidak jelas. Tampak pula perlemakan hati berupa sel-sel hati yang mengandung vakuol lemak. Terdapat dua jenis perlemakan hati pada sel ini yaitu perlemakan hati mikrovesikuler dan makrovesikuler. Perlemakan hati mikrovesikuler merupakan timbunan lemak dalam sel hati membentuk vakuola kecilkecil tetapi tidak sampai mendesak inti sel, sedangkan perlemakan hati makrovesikuler berupa sel-sel hati yang mengandung vakuola yang lebih besar dan hampir semua hepatosit terisi butiran lemak berukuran besar sehingga inti sel terdesak ke daerah perifer (Gambar 2).

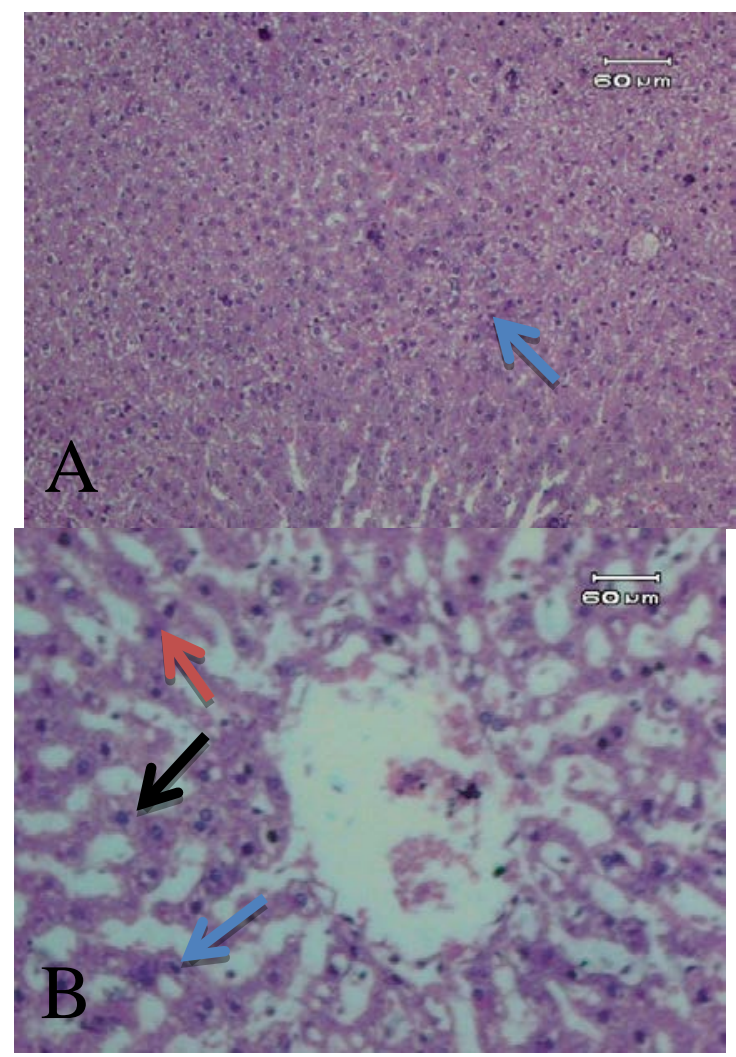

Gambar 2. Gambaran mikroskopik hati tikus wistar pemberian $\mathrm{CCl}_{4}$ 0,05 ml selama 5 hari. Ket: nekrosis (panah biru), perlemakan makrovesikuler (panah merah), perlemakan mikrovesikuler (panah hitam). A, Pembesaran 100x; B, Pembesaran 400x.

Pada kelompok 3 didapatkan gambaran sel-sel hati sudah mulai beregenerasi, ditandai dengan inti sel yang besar, sitoplasma luas dan lebih eosinofilik, tetapi arsitektur sel tidak teratur seperti susunan sel hati normal (Gambar 3).

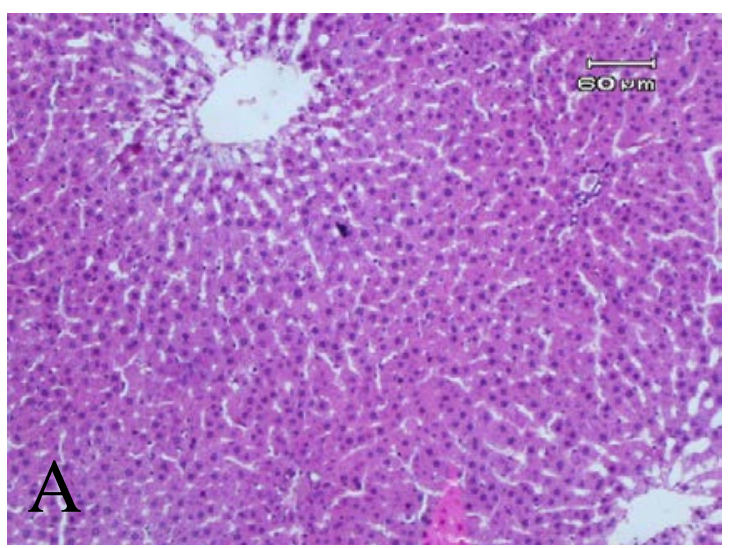




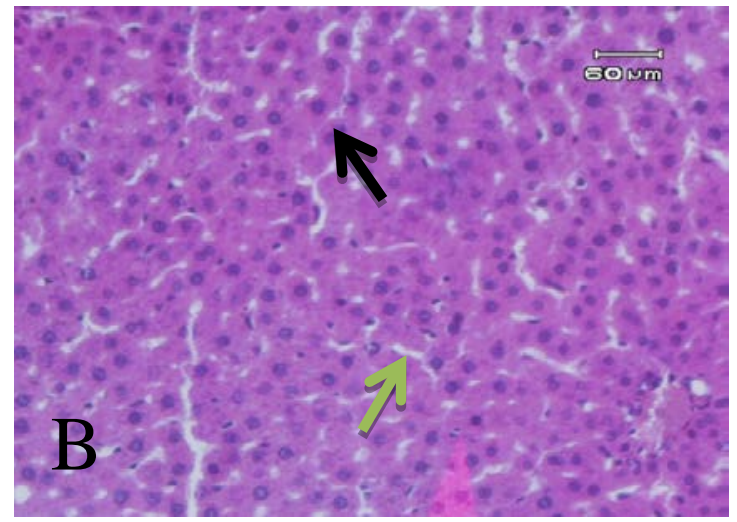

Gambar 3. Gambaran mikroskopik hati tikus wistar yang diberi $\mathrm{CCl}_{4} 0,05 \mathrm{ml}$ selama lima hari kemudian diberi minuman kopi $1 \mathrm{ml}$ selama tujuh hari. Tampak sel regenerasi (panah hitam), dan susunan sel tidak teratur (panah hijau). A, Pembesaran 100x; B, Pembesaran 400x.

Pada kelompok 4 didapatkan gambaran mikroskopik jaringan hati yang mirip dengan kelompok 3 (Gambar 4).
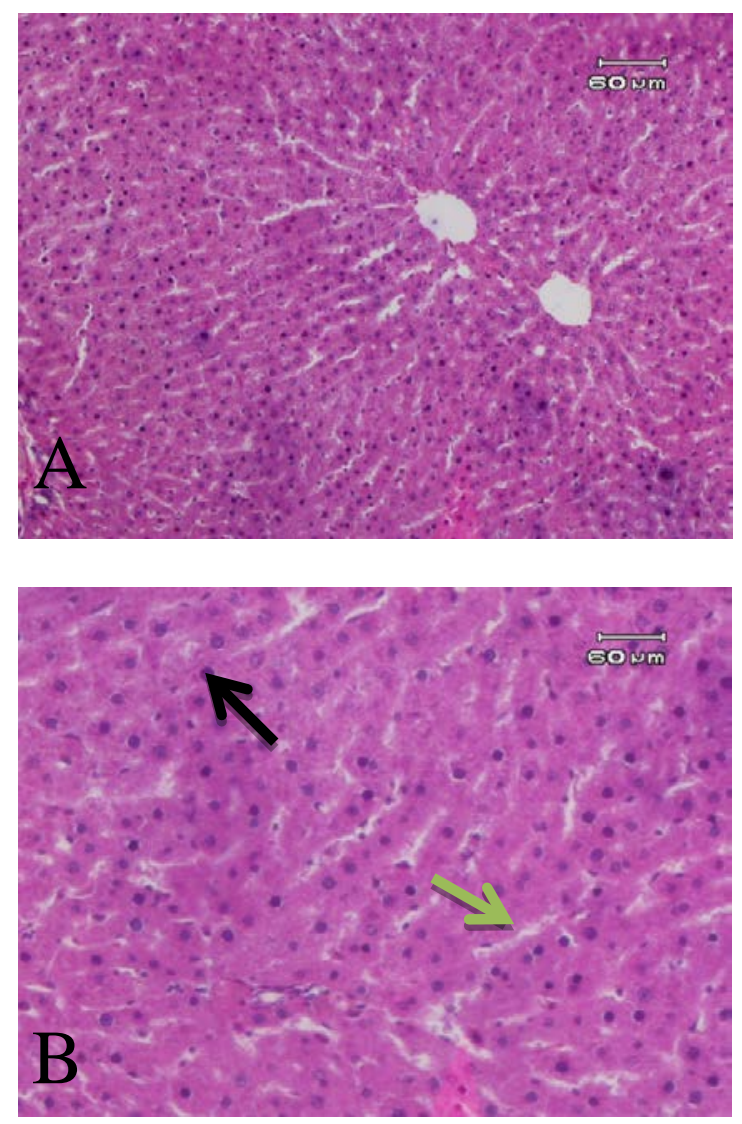

Gambar 4. Gambaran mikroskopik hati tikus wistar yang diberi $\mathrm{CCl}_{4}$ selama lima hari kemudian pellet biasa selama tujuh hari. Tampak sel regenerasi (panah hitam), dan susunan sel tidak teratur (panah hijau). A, Pembesaran 100x ; B, pembesaran 400X .

\section{BAHASAN}

Hasil penelitian ini memberikan informasi mengenai gambaran histopatologik hati tikus wistar yang diberi dan tidak diberi minuman kopi pasca induksi $\mathrm{CCl}_{4}$. Gambaran mikroskopik jelas menunjukkan perbedaan antara hati tikus kelompok kontrol negatif (kelompok 1) dan kelompok yang diberi $\mathrm{CCl}_{4}$ selama lima hari (kelompok 2) dan diterminasi hari ke6. Jaringan hati tikus kelompok 1 tampak normal. Pada kelompok 2 tampak adanya nekrosis dan perlemakan hati. Perlemakan hati ini terjadi karena karbon tetraklorida dengan aktivasi metabolisme oleh sitokrom P450 menjadi radikal bebas triklorometil $\left(\mathrm{CCl}_{3}\right)$. Triklorometil dengan oksigen akan membentuk triklorometilperoxi yang dapat menyerang lipid membrane endoplasmik retikulum. Triklorometilperoxi menyebabkan peroksidasi lemak sehingga merusak struktur dan fungsi retikulum endoplasmik. Cedera sel hati berupa perlemakan hati ini terjadi akibat penurunan sintesis apoprotein di hati sehingga transpor lemak dari sel hati yang keluar akan berkurang dan akhirnya lemak tertimbun dalam sel-sel hati. ${ }^{3}$ Cedera sel hati yang berat menyebabkan nekrosis sel. Stimulus yang cukup hebat dan berlangsung lama akan menyebabkan kematian sel dimana sel tidak lagi dapat mengkompensasi dan tidak dapat melanjutkan metabolisme. ${ }^{8,9}$

Pada kelompok tikus yang diberi $\mathrm{CCl}_{4}$ selama lima hari kemudian minuman kopi selama tujuh hari (kelompok 3) menunjukkan adanya regenerasi sel-sel hati. Hal ini sesuai dengan kepustakaan yang menyebutkan bahwa kopi memiliki beberapa senyawa polifenol yang salah satunya yaitu flavonoid (asam klorogenik) yang bersifat antioksidan kuat yang mampu mencegah kerusakan pada hati. ${ }^{10}$ Selain senyawa polifenol, kopi juga memiliki senyawa fenolik (asam klorogenat, asam ferulik, dan asam p-coumaric) yang juga bersifat sebagai antioksidan. ${ }^{11}$ Antioksidan mencegah kerusakan jaringan akibat radikal bebas (contohnya karbon tetraklorida) dengan mengurangi atau menghilangkan spesies oksigen reaktif. 
Antioksidan ini akan menetralisir senyawa radikal bebas dari $\mathrm{CCl}_{4}$ dan mencegah terjadinya reaksi berantai dengan cara mendonorkan elektronnya ke radikal bebas triklorometil dan triklorometilperoksil sehingga menjadi stabil. Selain itu antioksidan ini akan mengurangi otooksidasi lebih lanjut dari asam lemak pada fosfolipid membran sehingga regenerasi dari sel hati yang telah mengalami cedera dapat berlangsung. ${ }^{3}$

Gambaran mikroskopik hati tikus diberikan $\mathrm{CCl}_{4}$ selama lima hari kemudian pellet biasa tujuh hari (kelompok 4) menunjukkan hasil yang mirip dengan kelompok 3 yaitu terjadi regenerasi sel-sel hati. Regenerasi sel terjadi secara fisiologik. Kemampuan regenerasi sel tergantung pada jenis sel. Hepatosit merupakan jenis sel stabil, sel yang dianggap istirahat atau hanya mempunyai kapasitas regenerasi terbatas, tetapi mampu membelah diri dengan cepat dalam hal merespon cedera. Respon perbaikan hati secara fisiologik ini terjadi dalam waktu 57 hari. ${ }^{9}$ Hasil penelitian kelompok 4 dan kelompok 3 yang tidak jelas perbedaannya menunjukkan bahwa minuman kopi yang digunakan pada penelitian ini belum mempunyai efek dalam proses perbaikan jaringan hati yang rusak akibat $\mathrm{CCl}_{4}$. Namun demikian minuman kopi dapat menghambat terjadinya kerusakan sel lebih luas dan tidak memperburuk kerusakan sel yang ada. Hal yang mungkin berkaitan dengan hasil tersebut dan perlu diperhatikan untuk penelitian selanjutnya ialah jenis, lama, dan dosis pemberian minuman kopi serta individu atau subjek yang mengkonsumsinya.

Keterbatasan dari penelitian ini yaitu belum adanya referensi yang cukup mengenai tanaman kopi. Namun demikian, hasil penelitian ini menambah informasi dan pengetahuan mengenai efek dari minuman kopi terhadap kesehatan terutama organ hati dan untuk mengembangkan penelitian-penelitian yang berhubungan dengan minuman kopi.

\section{SIMPULAN}

Pemberian karbon tetraklorida $\left(\mathrm{CCl}_{4}\right)$ pada tikus selama lima hari menyebabkan terjadinya perubahan morfologik berupa adanya nekrosis dan perlemakan hati. Pemberian minuman kopi dosis $1 \mathrm{ml} / \mathrm{hari}$ selama tujuh hari pasca induksi karbon tetraklorida $\left(\mathrm{CCl}_{4}\right)$ selama lima hari menunjukkan gambaran histopatologik berupa regenerasi sel-sel hati yang mirip dengan regenerasi sel-sel hati yang terjadi secara fisiologik.

\section{SARAN}

Bagi peneliti selanjutnya diharapkan dapat melakukan penelitian tentang efek minuman kopi dalam jangka waktu yang bervariasi dan dalam beberapa dosis yang berbeda serta perlu dipelajari lebih lanjut bagaimana efek minuman kopi terhadap organ hati.

\section{DAFTAR PUSTAKA}

1. Chandrasoma $\mathbf{P}$, Taylor $\mathbf{C R}$. Ringkasan Patologi Anatomi (2nd ed). Jakarta: EGC, 2005; p. 574-95.

2. Singh A, Bhat TK, Sharma OP. Clinical biochemistry of hepatotoxicity. J Clinic Toxicol S4. 2011;001:1-19.

3. Muriel P, Arauz J. Coffee and liver health. Dalam: Chu YF, penyunting. Coffe emerging health effects and disease prevention (1st ed). Delhi: IFT Wiley-Blackwell, 2012; p. 128-29.

4. Panjaitan RGP, Handharyani E, Masriani, Zakiah Z, Manalu W. Pengaruh pemberian karbon tetraklorida terhadap hati dan ginjal tikus. Makara Kesehatan. 2007;11:116.

5. Marks DB, Marks AB, Smith CM. Biokimia Kedokteran Dasar: sebuah pendekatan klinis. Jakarta: EGC, 2013; p. 330.

6. Badan POM RI. Sentra Informasi Keracunan Nasional (SIKerNas) Pusat informasi Obat dan Makanan. Jakarta: Badan POM RI; 2010.

7. Rukman HR. Untung selangit dari agribisnis kopi (1st ed). Yogyakarta: Lily Publisher, 2014; p. 24-30.

8. Maramis RK, Citraningtyas G, Wehantouw F. Analisis kafein dalam 
kopi bubuk di kota Manado menggunakan spektorfotometri UVVIS [Tesis]. Manado: Farmasi FMIPA Universitas Sam Ratulangi; 2013.

9. Wilson LM. Cedera dan kematian seluler. In: Price SA, Wilson LM, penyunting. Patofisiologi konsep klinis proses-proses penyakit (6th ed). Jakarta: EGC, 2012; p. 42-9.

10. Johnston KL, Cliffrod ML, Morgan ML. Coffee acutely modifies gastro- intestinal hormone secretion and glucose tolerance in humans: glycemic effects of chlorogenic acid and caffeine 1-3. The American Journal of Clinical Nutrition. 2003;78:728-33.

11. Garcia EL, Dam RMV, Qi L, Hu FB. Coffee consumption and markers of inflammation and endothelial dysfunction in healthy and diabetic women 1-3. The American Journal of Clinical Nutrition. 2006;84:888-93. 